\author{
Кэйко Митани \\ Токийский университет \\ (Япония, Токио) \\ kmitani@mb1.suisui.ne.jp
}

\title{
ТЕКСТОЛОГИЧЕСКИЙ И ЛИНГВИСТИЧЕСКИЙ АНАЛИЗ СПИСКОВ ДЕЯНИЙ АПОСТОЛОВ ПЕТРА И АНДРЕЯ В СТРАНЕ ВАРВАРОВ
}

\begin{abstract}
Статья посвящена текстологическому и лингвистическому анализу славянских списков апокрифического повествования «Деяния апостолов Петра и Андрея в стране варваров». Памятник относится к числу апокрифических сочинений о деяниях апостолов, созданных в III-IV вв. в раннехристианской культурной среде. Памятник пришел из Византии в славянский мир достаточно рано - до XII в. В настоящее время он известен в четырех списках, из которых три фрагмента находятся в древнерусских рукописях, а один, представляющий полный текст памятника, входит в состав хорватской глаголической рукописи. Текстологический анализ славянских списков показывает, что все четыре списка восходят к одному церковнославянскому переводу, при этом глаголическая копия переписана с кириллического источника. Текст глаголического хорватского списка вполне совпадает с греческим оригинальным текстом, при этом в его языке наблюдаются отклонения от церковнославянской нормы в сторону народного языка. Текстологические особенности русских списков восходят к древнейшему этапу рукописной истории памятника.
\end{abstract}

Ключевые слова: история славянской переводной литературы, апокрифы, славянские рукописи.

\section{1. О памятнике}

«Деяния апостолов Петра и Андрея в стране варваров» (далее ДПиА) известны в научной литературе также под названиями «Слово святых апостол: Петра и Андрея, Матфея и Руфа, и Александра» [Понырко 1987] и «Хождение апостолов Петра и Андрея, Матфея и Руфа, и Александра» ${ }^{1}$. Памятник относится к числу апокрифов о хождениях и мученичестве апостолов, которые создавались во время раннего хри-

\footnotetext{
${ }^{1}$ Издано под этим названием Н. С. Тихонравовым [Тихонравов 1863: 5-10].
} 
стианства. Помимо ДПиА, об апостоле Андрее рассказывают и другие апокрифические сказания - «Деяния Андрея и Варфоломея» и «Деяния Андрея и Матфея в стране антропофагов» [Понырко, Панченко 1987]. Предание о посещении Русской земли апостолом Андреем, засвидетельствованное в древнерусских летописях [ПВЛ 1996: 9], могло быть связано с некоторыми подобными сказаниями об апостольских походах Андрея по Черному морю.

Наличие в тексте ДПиА упоминаний о пребывании Андрея со спутниками в го-

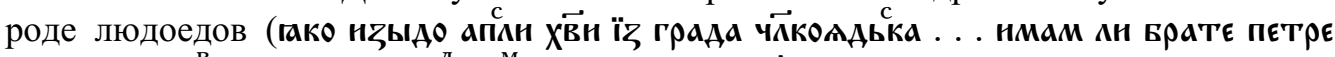

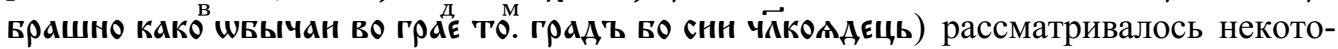
рыми исследователями как признак связанности ДПиА и «Деяний Андрея и Матфея в стране антропофагов» и указание на то, что эти два апокрифа являются составными частями одного византийского памятника. Однако нельзя не учитывать самостоятельность рукописной традиции этих двух памятников на византийской почве, а также разные пути распространения их переводов. Кажется более вероятным, что эти тексты появились не одновременно: «Деяния Андрея и Матфея» были созданы раньше - возможно, в III в., а ДПиА появились около IV в. в качестве продолжения «Деяний Андрея и Матфея» [Elliott 1993: 240].

ДПиА включают три основных эпизода, в которых описываются чудеса, совершаемые апостолами. Первое чудо было явлено старцу, пахавшему поле перед воротами города варваров, куда были отправлены апостолы. Когда старец уходит в город за хлебом для апостолов, они в благодарность вспахивают и засевают его поле, и до возвращения старца нива приносит богатый урожай. Второе чудо совершается перед жителями города, поставившими нагую блудницу перед городскими воротами, чтобы воспрепятствовать вхождению апостолов в город. Однако Андрей с помощью архангела Михаила высоко вознес блудницу за волосы на воздух, что позволило апостолам пройти в ворота. Третье чудо связано с евангельскими словами: «Легче верблюду пройти сквозь игольное ушко, чем богачу войти в царствие небесное» (Мф 19, 24; Лк 18, 25). Петр произносит эти евангельские слова в споре с богатым городским жителем Онисифором, чем вызывает у богача враждебную реакцию. Но потом, по молитве Петра, происходит чудо: игольное ушко увеличивается и приведенный верблюд проходит через него. Увидев это чудо дважды, Онисифор вслед за всеми жителями города обращается в христианство.

\section{2. Происхождение и переводы ДПиА}

Списки ДПиА известны нам на греческом, эфиопском, арабском и церковнославянском языках ${ }^{2}$. Оригиналом считается греческий текст, озаглавленный в списках:

2 ДПиА распространено менее, чем его «старший брат», «Деяния Андрея и Матфея», списки которого имеются, кроме славянских, на греческом, латинском, сирийском, армянском, коптском, арабском и эфиопском языках. 


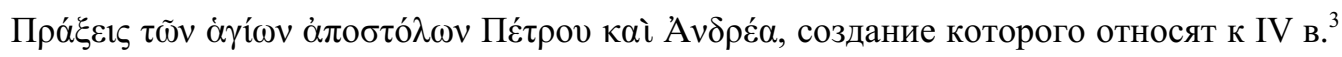
В некоторых списках эфиопского и арабского переводов в качестве главного героя появляется не Андрей, а Фаддей и, наряду с этим, наблюдаются небольшие содержательные изменения, но основная линия повествования в них остается неизмененной [Elliott 1993: 231-244 (в особенности 242-243); Malan 1871: 221-229; Lewis 1904: 120-125; Budge 1901]. Эфиопский текст был переведен на английский С. Маланом [Malan 1871: 120-125], а арабский перевел на английский А. Льюис [Lewis 1904].

Славянские списки стали известны в Западной Европе благодаря статье Бонветча [Bonwetsch 1882], который опирался на публикации Тихонравова [Тихонравов 1863] и исследование В. Васильевского [Васильевский 1877: 58-76]. Позднее К. Истомин опубликовал древнейший список ДПиА, датируемый ХІІ в. [Истомин 1904]. Тем не менее, славянская традиция апокрифических повествований об апостолах, в том числе ДПиА, остается недостаточно исследованной. В русской научно-справочной литературе отсутствуют упоминания о хорватском глаголическом списке ДПиА ${ }^{4}$. Самым значительным трудом по славянским спискам ДПиА до настоящего времени остается статья [Grabar 1967] $]^{5}$, но она сосредоточена в основном на анализе глаголического списка и не учитывает данные наиболее древнего русского списка ДПиА. Очевидно, что этот памятник нуждается в более подробном рассмотрении.

\section{3. Славянские списки}

\section{1. Хорватский глаголический список}

Хорватский глаголический список ДПиА, включенный в сборник Жгомбича (Žgombićev zbornik, HAZU XII.30) - единственный известный нам список полного славянского текста ДПиА, в основном соответствующий Ватиканскому списку греческого текста ${ }^{6}$. Сборник обнаружил И. Милчетич в 1882 г. во францисканском монастыре на острове Крк в северной Далмации, назвав его по имени тогдашнего на-

${ }^{3}$ Изд.: [Tischendorf 1866: 161-167; Bonnet, Lipsius, Tischendorf 1898: 117-127]. Английский перевод греческого текста сделан Уокером по изданию Тишендорфа [Walker 1870: 368-373].

${ }^{4}$ См., например, [Понырко 1987; Понырко, Панченко 1987].

${ }^{5}$ Публикация списка в транслитерации латиницей - c. 200-206.

${ }^{6}$ Критическое издание греческого текста [Bonnet, Lipsius, Tischendorf 1898: 117-127] осуществлено на основе списка Бодлеанской библиотеки (Baroccianus 180), относящегося к XII в., с дополнениями и исправлениями по Ватиканскому списку (Cod. Vaticanus gr. 1192) XV в. Сравнивая эти греческие списки с хорватским глаголическим списком, Б. Грабар обнаружила, что глаголический список ближе к Ватиканскому списку, чем к Бодлеанскому. Например, в самом начале повествования в нем читается «kade bě Petarь i Matei i Alek'san'darb i Rupь». Аналогичный состав имен

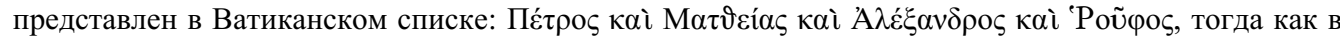
Бодлеанском списке имя Руфа отсутствует. Об отношении текстологических особенностей глаголического текста к греческим спискам см. [Grabar 1967: 179-180]. 
стоятеля монастыря Е. Жгомбича. Сборник представляет собой бумажную рукопись объемом $1+125$ л., состоит из трех частей, написанных в разное время - от начала до конца XVI века, объединенных в один сборник в конце того же века ${ }^{7}$. Список ДПиА в сборнике Жгомбича (далее CŽg) находится на л. 100-106 и относится к самой старой части сборника, созданной в 1520-30 гг. Местом создания CŽg считается восточная область полуострова Истрия [Milčetić 1902; Grabar 1967; Štefanić 1970: 40-45; Sudec 2012; Badurina-Stipčević 2015].

Языковые особенности CŽg описаны в [Grabar 1967]. Отметим лишь несколько фактов, интересующих нас в связи с настоящей работой ${ }^{8}$. Праславянский *е̌ в большинстве случаев реализуется в $e: v e m$ ' < věděti (ст.сл. в\$А А b, b > a: starac' (ст.-сл. старьць), dan' (ст.-сл. дьнь); *dj > j: viju (ст.-сл. внжаү); $\check{z}>r$ : ne moremo (103r). На морфологическом уровне можно наблюдать параллельное употребление старых и новых форм: $v$ dome $-v$ domu; ego - nega. В качестве относительных местоимений появляются диалектные формы $k i, k a$, кроме одного случая употребления книжного местоимения iže (им. п. мн. ч). Что касается вопроситель-

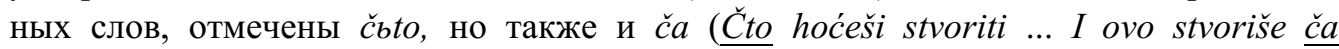
zapovede imь (103r)). Эти признаки указывают на то, что данный список был написан на смешанном церковнославянско-народном языке с заметными признаками чакавского наречия с екавизмом, т. е. с рефлексом $e$ из *ё.

Смешанный характер языка наблюдается также в спряжении. Например, наряду со старым окончанием наст. вр. 1 л. ед. ч. - $и$-jи обнаруживается окончание -mь: govoru, stvoru, но boim'se; učinimb. Аорист в большинстве случаев имеет сигматические формы: idoh', rekoh'; vzradovaše, razumeše. Встречается новая диалектная форма otrekos'mo se. Для выражения будущего времени в основном употребляются формы с глаголом hotěti: ako oćeši poiti i prnesti nam; hoću iti i prinesti vam' brašna (101r). К числу древних морфосинтаксических особенностей относится употребление дательного самостоятельного: biv 'šimb nimb bliz' gradu toga (100v); ovo govorećim' imb (100v).

В качестве следов языковой древности источника необходимо особо отметить употребление двойственного числа: A voli č'ê esta? Otveća starac': moê nesta da esam' e naelb. (101r); An'drei biše za volma (101r); pred' nogama ap(osto)lb (101v). Так как двойственное число в чакавском наречии ко времени создания списка уже было утрачено [Kapetanović 2011: 93], нет возможности считать употребление двойственного числа особенностью языка переписчика CŽg. Особенно важен пример An'drei biše

${ }^{7}$ В данный сборник, как и в другие хорватские глаголические сборники, составленные в XV-XVI вв., включены разные неканонические переводные тексты (например, Луцидар - своеобразная средневековая энциклопедия, ветхозаветные и новозаветные апокрифы, а также агиографические легенды).

${ }^{8}$ Ниже в примерах используется ерчик (апостроф), употребление которого на месте еря характерно для средневековых хорватских глаголических памятников [Damjanović 2008: 53-54], например, boim' se вместо boimb se. 
$\underline{\text { za volma }}$ (101r) из описания апостольской пахоты, поскольку в греческом тексте

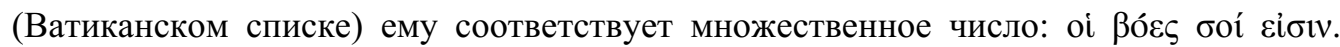
Этот пример свидетельствует, по-видимому о том, что в языке, на котором был создан антиграф CŽg, двойственное число еще сохранялось.

Б. Грабар обнаружила, что CŽg восходит к кириллическому источнику. Одним из самых надежных доказательств этого является ошибка при передаче числа. Споря с Петром о вере, Онисифор упоминает о своем богатстве: imamb . . č čtrdesetb $i$ devetb

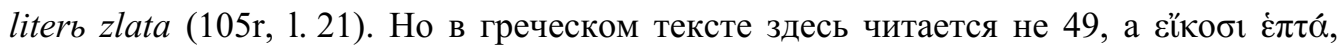
т. е. $27^{9}$. Это расхождение в числах находит простое объяснение в различии числовых значений между глаголическими и кириллическими буквами. Число 27 обозначается в кириллице как . 40 , а буква $0^{\circ}(3)-$ не 7 , а 9. Легко догадаться, что число, написанное кириллицей как . глаголицу [Grabar 1967: 165].

Предположение о существовании кириллического источника для CŽg хорошо согласуется с тем фактом, что хорватская средневековая традиция апокрифической и другой неканонической литературы формировалась в связи с кириллическими источниками - прежде всего сербскими, но также и болгарскими и русскими [Štefanić 1969: 13].

\section{2. Древнерусские списки}

В настоящее время известны три русских списка ДПиА ${ }^{10}$ :

F46 - РНБ, F.п.I.46. Златоструй краткой редакции и отрывок сборника. XII в. Сборник написан в два столбца. ДПиА - л. 112-112 об. (без нач.). Издан К. Истоминым [Истомин 1904] и О.В. Твороговым (отрывок) [Творогов 1993: 30-32].

S - РНБ, Соф. 1261. Сборник поучений Кирилла Туровского, слов и чудес. XIV-XVвв. ДПиА - л. 25-25об.

T - РНБ, F.п.1.39. Толстовский сборник. XVII в. Издан Н. С. Тихонравовым [Тихонравов 1863].

Во всех древнерусских списках текст ДПиА не полон. Список F46 начинается со второго чуда, с того места, когда старейшины города пытаются воспрепятствовать апостолам войти в город, и обрывается на середине изложения третьего чуда. Этот список содержится в сборнике, в котором перед списком ДПиА находится неполный список «Сказания об апостолах Петре и Павле», а после него - отрывок списка «Житие пророка Ильи» [Творогов 1988: 199]. Орфография этого списка включает особенности, характерные для древнерусских рукописей XI-XII вв. [Дурново 2000].

${ }^{9}$ В русских списках соответствующая часть, к сожалению, утеряна.

10 Описание сборников: [Гранстрем 1953: 19, 59; Творогов 1988: 197-214;198-199, 205]. Цитаты в настоящей работе взяты: T — из Тихонравова, F46 и S - из рукописей F.п.I.46 и Соф. 1261, РНБ. 


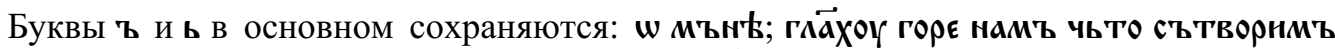

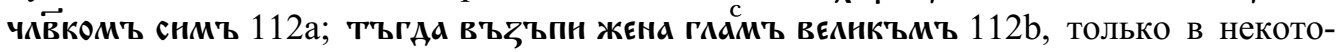
рых случаях они пропущены: всьмь $112 \mathrm{~b}$; мнози 112b. Буквы ж и њ вообще не употребляются, вместо них пишутся оү и ю. Смешиваются ж с а и га, так что после шипящих пишется а: г्रаша 112a; пр\$даша 112b; чадү 112a, в начале слова и после

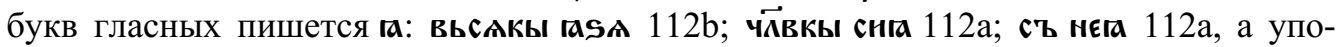
требление А вместо а наблюдается после смягченных согласных: въХ0Алцниъъ 112b; ненавндАТЬ 112a; днвлАХY $112 \mathrm{~b}$. Восточнославянское ж на месте *dj представлено написаниями с ж: внжю 112 с и одєжү $112 \mathrm{~b}$. Слоговая структура ${ }^{*}$ ТьрT передается древнерусскими написаниями: навьржє 112с; жєстосьрдын 112с; существительные в тв. пад. ед. ч. м. и с. рода имеют древнерусское окончание -ъмь: и зиатъъмь и внсьръмн; Аत्ХЪмь стыммь $112 \mathrm{~b}$.

Список $\mathrm{S}$ тоже не имеет начала и конца, но, несмотря на то, что он еще короче, чем F46, он имеет заглавие: «Ямово стүго апола пєтра и андр‡га». Список Т начина-

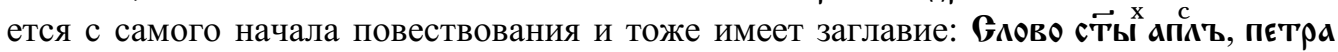

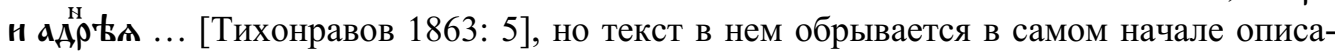
ния третьего чуда. Ниже показано соотношения частей повествования, представленных в славянских списках:

\begin{tabular}{|c|c|c|c|c|}
\hline & заглавие & 1-й эпизод & 2-й эпизод & 3-й эпизод \\
\hline $\begin{array}{l}\text { Греч. } \\
\text { оригинал }\end{array}$ & 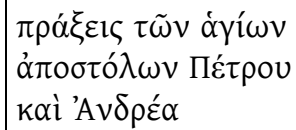 & & & \\
\hline CŽg & $\begin{array}{l}\text { Čtenie stago } \\
\text { An'dreê apustola }\end{array}$ & & & \\
\hline F46 & - & & 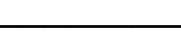 & \\
\hline S & 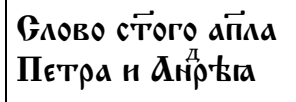 & & & \\
\hline $\mathrm{T}$ & 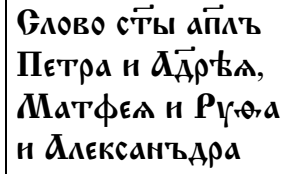 & & & \\
\hline
\end{tabular}

Puc. 1. Части повествования в списках ДПиА 


\section{4. Сопоставление славянских списков}

4.1. Текстологическое изучение славянских списков ДПиА затруднено из-за фрагментарности древнерусских списков, но в определенной степени их сопоставление все-таки возможно. Сравним начало S и соответствующее место в F46:

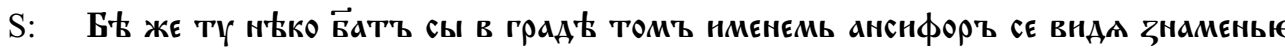

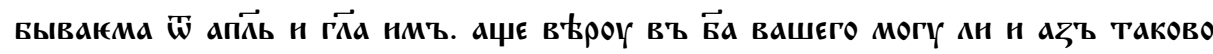

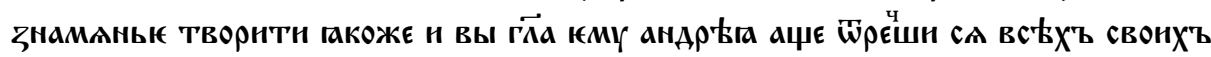

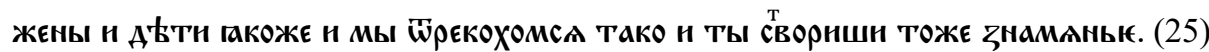

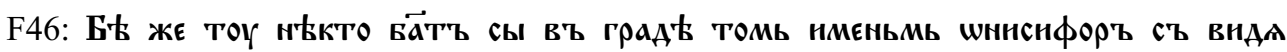

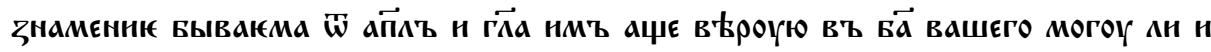

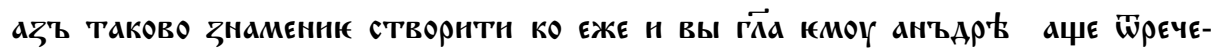

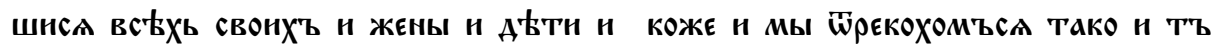
СЪТВОРНШН ЗНАМЕННК ТОЖЕ. (112с)

Как нетрудно отметить, эти фрагменты почти полностью совпадают, незначительно отличаясь орфографией и написанием имени шннснфоръ - анснфоръ.

Сопоставление F46 и T также обнаруживает достаточно высокую степень текстологической близости этих списков. Приведем в качестве примера фрагмент, в котором старейшины города советуются, как им прогнать апостолов, пришедших к городу:

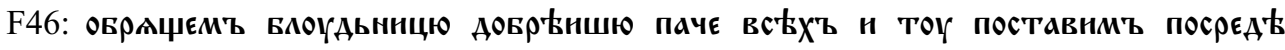

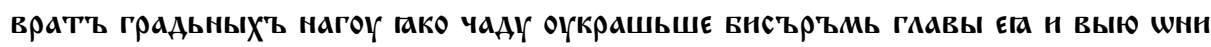
ЖЕ ВЪҚЬРЬВЪШЕ НА НЮ И ПОБЪГНОГТЬ И НЕ ВЪННАОГТЬ ВЪ ГРААЪ НАШЬ ШНН ЖЕ

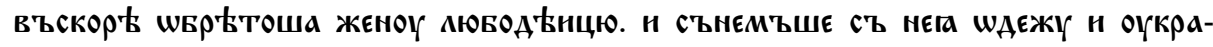

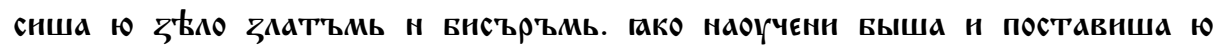

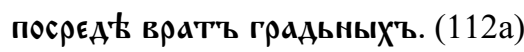

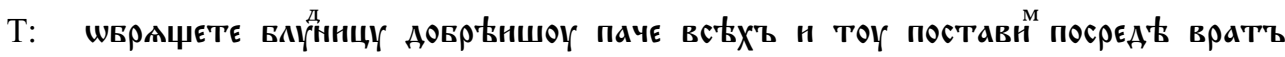

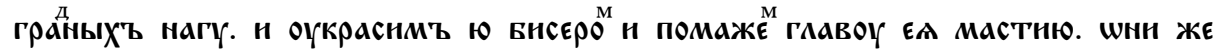

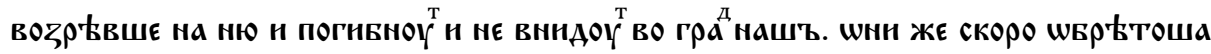

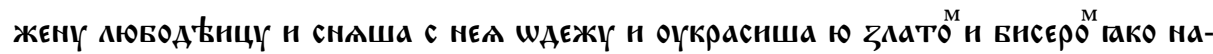

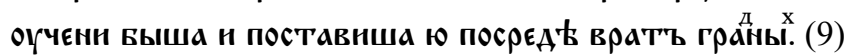

Однако между этими списками все же наблюдаются некоторые расхождения. Например, имеющийся в F46 сравнительный оборот гако чаду (его нет в греческом тексте) отсутствует в T, а на месте представленной в F46 причастной группы оүкрашьше внсъръмь главы єга и выю в Т читается финитная форма глагола настоящего времени: оцКраснмъ ю внсеро н помажё гАавоу єА мастню. Кроме того, 
глаголу пов Һгногть в F46 соответствует погньноу в $\mathrm{T}^{11}$. Тем не менее исходный текст памятника в списке Т в основном сохраняется.

Таким образом, можно заключить, что все три русских списка восходят к одному источнику.

4.2. Перейдем к сравнению CŽg с древнерусскими списками в пределах той же части, которую мы использовали при сравнении F46 и S.

CŽg: I bě v gradu tomь č(lově)kь bogatı velmi imenemь Onisiporı. Videvb znameniê ot ap(osto)lb i reče ims: veruju v B(og)a vašego ako mogu znameniê stvoriti kako vi tvorite. I reče An'drei: Ašće otrečeši se vsego imeniê svoego i ženi i čedı svoihь kako i mi otrekos'mo se tagda stvoriši znameniê kako i mi. (104r)

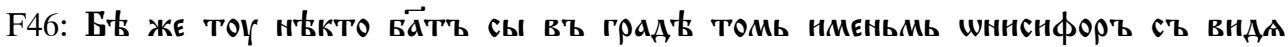

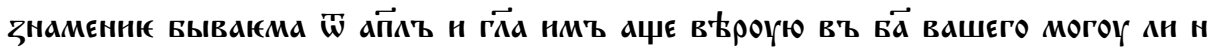

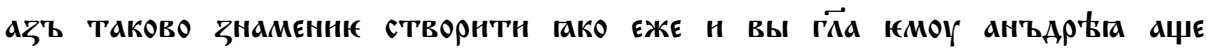

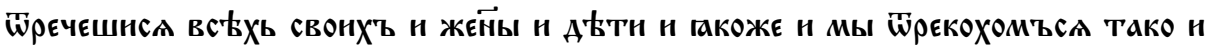
Т'Ъ СЪТВОРНШН ЗНАМЕнНІ ТОЖЕ. (112c).

Расхождения между CŽg и F46 - довольно существенные, они затрагивают и синтаксис и лексику (ср. ako, kako, reče в CŽg, но ащє, гако, глагола в F46). Тем не менее родство этих списков несомненно.

Не менее значительные различия наблюдаются между CŽg и T, как показывает сравнение в них начальной части текста:

CŽg: Petarı i An’drei i Alek’sandarı i Matei i Rup' idoše v gradı barbarski. I biv’šimь nimь bliz' grada toga i reče An'drei Petru: Brate Petre, bude li nam’ muku trpeti totu kako sam' ju ja trpelı v grade č(lově)koêdac'? I reče nemu Petarı: Ovo e č(lově)kь starı pred' nami na nivi svoei. $(100 \mathrm{v})$

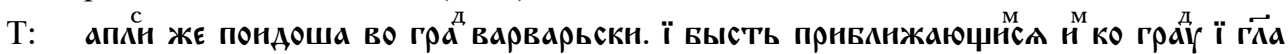

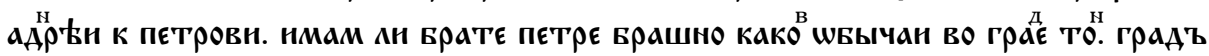

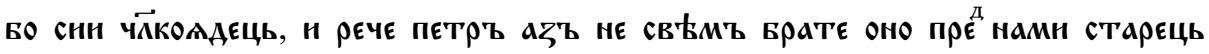

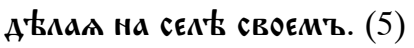

CŽg и T различаются, в частности, тем, что в хорватском списке пишутся все имена апостолов, а в Т они обозначены лишь как апостолн. Есть и другие сущест-

${ }^{11}$ В глаголическом списке в данном месте читается только «...ukrasiv’še ju i nagu postavimo ju pred vrati grada i oni ne vnidutb v gradь naš» $103 \mathrm{r}$; ср. в соответствующем месте греческого текста:

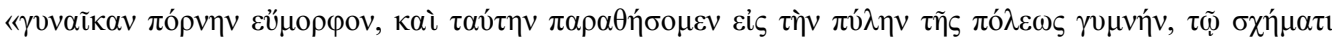

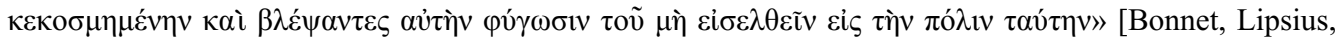
Tischendorf 1898: 122]. 
венные различия, например в обращении Андрея к Петру. Несмотря на эти несовпадения, CŽg и Т принадлежат, безусловно, к одному переводу. Об этом свидетельствует, во-первых, использование дательного самостоятельного оборота в одном и том же месте: (Т) Бысть прнвлнжающнска и ко гра̊̆; (CŽg) biv’šimь nimь bliz’ grada $\operatorname{toga}^{12}$. Во-вторых, в обоих списках Андрей обращается к Петру вратє пєтрє (brate

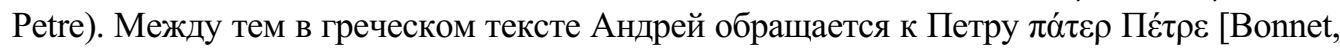
Lipsius, Tischendorf 1898: 118]. Такие совпадения трудно объяснить случайностью.

Сказанное позволяет заключить, что все славянские списки восходят к одному источнику, общему для них переводному тексту греческого оригинала. Обозначим его QS.

4.3. Наличие общего источника не обязательно предполагает полное совпадение славянских списков. Сравним CŽg и русские списки в части, касающейся второго чуда, и отметим расхождения между ними:

CŽg: naidimo ednu ljubodeicu ukrasiv’še ju i nagu postavimo ju pred vrati grada i oni ne vnidutb v gradb naš'. I ovo stvoriše ča zapovede imb i postaviše ju nagu pred vrati. (103r)

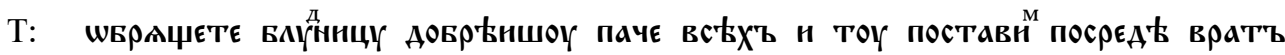

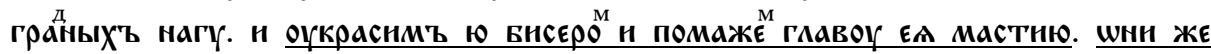

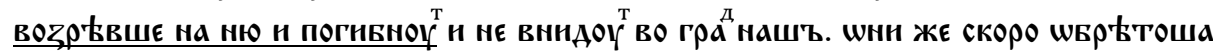

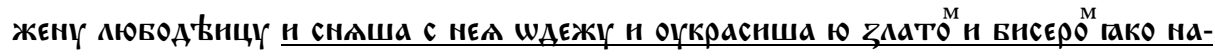

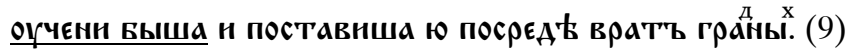

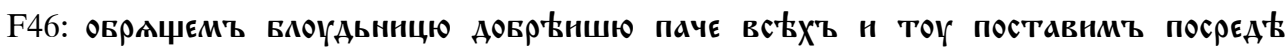

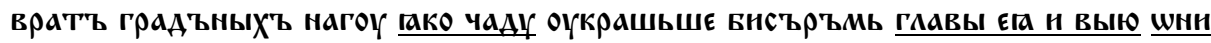

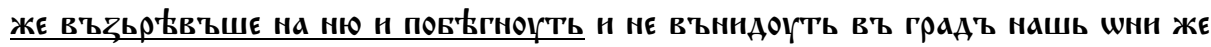

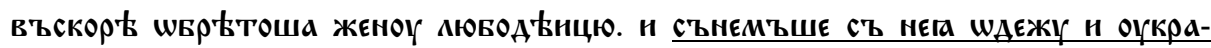

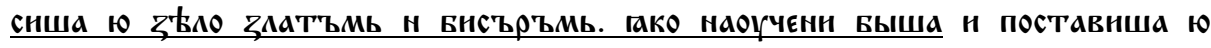
посредЬ врат"' градьныХ'ъ. (112а)

Подчеркнутые части, имеющиеся в русских списках, отсутствуют в CŽg. Нет их и в греческом тексте [Grabar 1967: 203; Bonnet, Lipsius, Tischendorf 1898: 121]. Следовательно, можно предположить, что на основе QS был создан один список, к которому непосредственно или опосредованно восходит CŽg, и другой список, с незначительным изменениями, к которому восходят древнерусские списки. Данное предположение подтверждается следующим расхождением между T и CŽg:

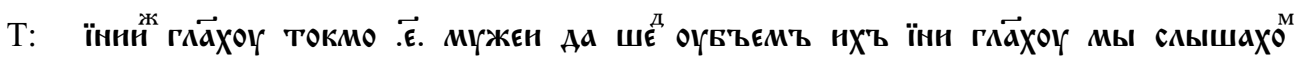

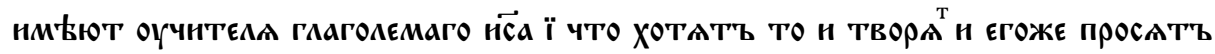

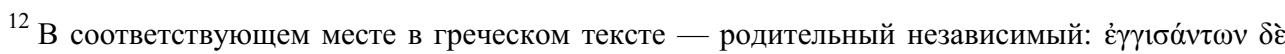

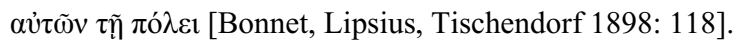




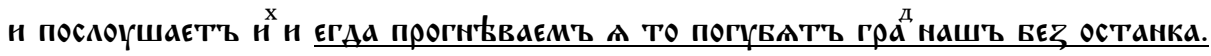

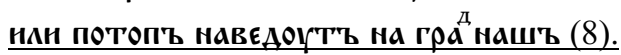

CŽg: A drugi rekoše .d. muži nihь e(stь) šad'še ubiimo e. A ini rekoše ne moremo ih' mi ubiti. Slišasmo koga učitela imaju I(su)sa imenemь i čakole prosetı od nego dastı imь kada sprosetb. Eda kako ogan' sprosetb od nego i sažgutb nasь. I plakahu se govoreće Gore namb. (103r)

В Т мы читаем «потопъ навєдоүтъ на гра нашъ», тогда как в соответствующем месте глаголического списка читается «Eda kako ogan’ sprosetь od nego i sažgutь nasь».

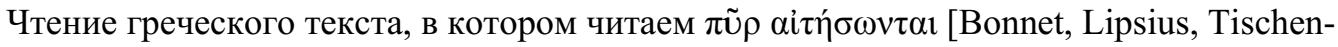
dorf 1898: 121], показывает, что русская версия потопь - результат изменения.

4.4. Отметим некоторые различия в древнерусских списках, важные для выяснения их текстологических взаимоотношений. В следующем месте Т оказывается ближе к Č̌g, чем F46:

CZg: pošli an'j(e)la tvoego Mihaila da obesit' ju za vlasi na aere dokle vnidemo v gradb i propovemo e(van)j(e)lie c(ěsa)rıstvie b(o)žiê. i prileti an’jelı i postavi ju va aeri visoko za vlasi. (103v)

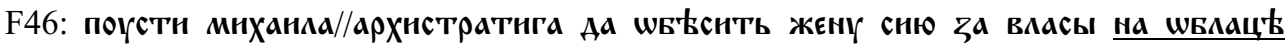
АОНЪАЕЖЕ ВЪННАЕМЪ ВЪ ГРААЪ СЬ И ПРОПОВЪМЫ САОВО НСТННЬНОК И КГАА НСХОААЧЕ НЗ ГРААА ПОВЕАНМЪ Ю СЪНАТН СЪ ШБААКА Н АБН (!) ПО САОВЕСЕХҚ СНХЪ. (112а)

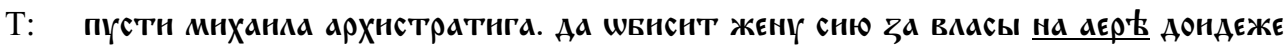

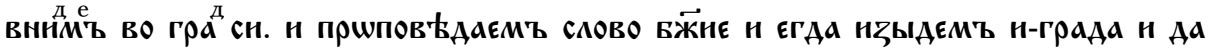

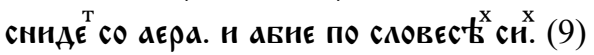

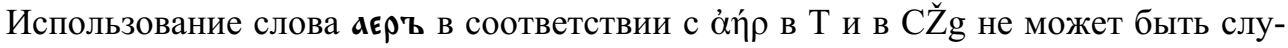
чайным совпадением. Очевидно, что на аєрь является исходным чтением, а на шБлацт - инновацией древнейшего списка F46.

В Т содержится написание єрєсн на месте е̂rosti ('ярости', ср. ст.-сл. Њрость) в CŽg, которому в F46 соответстсвует вариант гкњва:

CŽg: Edin' že od nih' plnь êrosti i reče imь ako mene poslušaete . . . (103r)

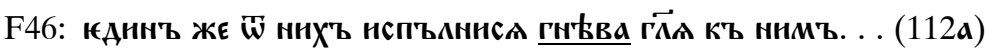

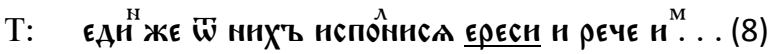

Очевидно, что исходным является чтение њростн. Вариант єрєсн появился в Т в результате искажения этого слова ${ }^{13}$, а вариант гнњва в F46 - вследствие лексической замены.

${ }^{13}$ Следует, впрочем, заметить, что список Т в целом содержит меньше ошибок и описок, чем F46, ср. в последнем: аБн (Т: авнє); ХотАхог въти (Т: въннти) и др. 
Это позволяет сделать вывод о том, что T не связан непосредственно с F46, а восходит к более старому русскому списку, чем F46. Текстуальное соотношение четырех списков ДПиА может быть представлено следующим образом.

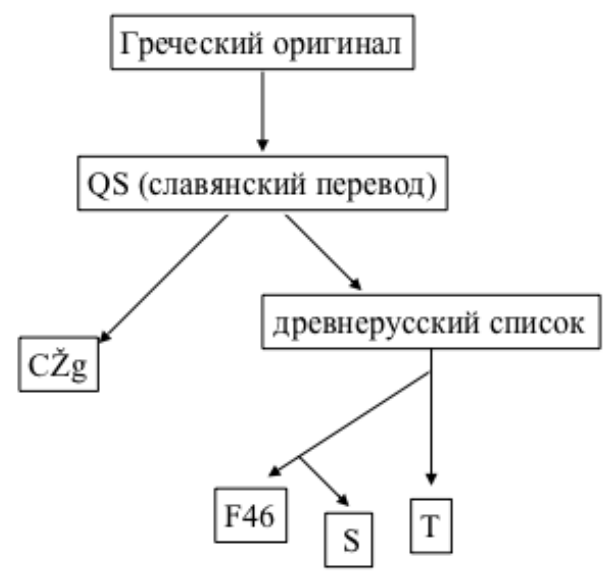

Puc. 2. Текстуальное соотношение славянских списков ДПиА

\section{5. Заключение}

Приведенные наблюдения показывают, что CŽg и русские списки восходят к общему источнику. Отсутствие следов значительных изменений в русских списках, в том числе в $\mathrm{T}$, указывает на то, что этот список отделен от исходного текста славянского перевода небольшим количеством списков. В целом, древнерусские списки, несмотря на их фрагментарность, неплохо сохраняют исходный текст славянского перевода ДПиА.

Лексика древнерусских списков ДПиА находится вполне в русле кирилло-мефо-

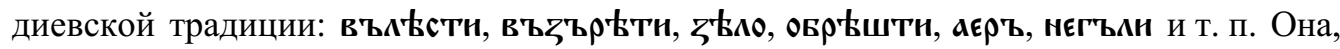
в частности, сохраняется в евангельской цитате, которую произносит Петр в споре с Онисифором:

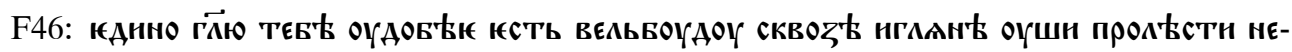

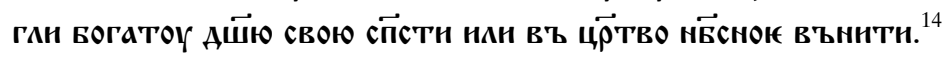

${ }^{14}$ Ср. в других списках:

CŽg: Azb edidnoju govoru, da e lagle vel'bludu skoze uši igleni proiti nego li bogatomu v crstvo božie vnit

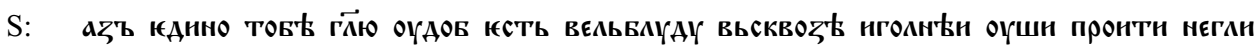

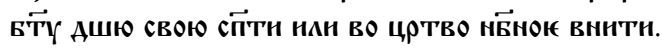


Ср. соответствующее место в старославянском переводе евангелия по Мариинскому и Зографскому спискам:

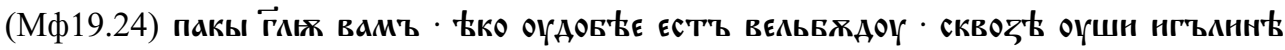

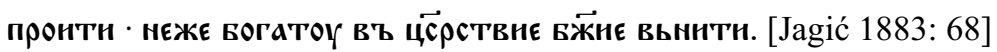

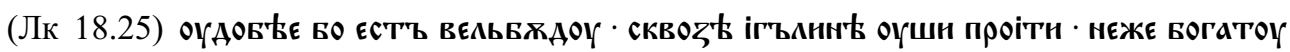
вь цр्сье Бӝне вьннтн. [Jagić 1879: 121].

Архаические особенности языка сохраняются и в хорватском списке. К приведенным примерам сохранения в CŽg двойственного числа можно добавить еще один в описании того, как, по молитве Петра, ушко у иглы расширилось и в него смог пройти верблюд. В славянском тексте ДПиА парное существительное оүшн согласовано с формой аориста в двойственном числе (otvorista se - по-видимому, искаженНое отворнстесе):

Videv’ že Petarı iglu položenu i velbuluda stoeće i vzapi glasom' veiemь... I otvorista se uši igli i biše êko vrata veliê i proidê velbludb. videv’ vasь narodı čudo i reče Petarı vnidi paki skozi i proide takoe. (105r)

Совокупность этих данных указывает на то, что апокрифическое сказание ДПиА было переведено на славянский язык в древнейший период истории славянской письменности.

\section{Литература}

Badurina-Stipčević 2015 - V. Badurina-Stipčević. Glagoljski Žgombićev zbornik kao književni izvor // Kolo, 2. 2015 (http://www.matica.hr/kolo/460/).

Bonnet, Lipsius, Tischendorf 1898 - M. Bonnet, R. A. Lipsius, C. Tischendorf. Passio Andreae. Ex actis Andreae. Martyria Andreae. Acta Andreae et Matthiae. Acta Petri et Andreae. Passio Bartholomaei. Acta Joannis. Martyrium Matthaei. Leipzig, 1898.

Bonwetsch 1882 - N. Bonwetsch. Ein Beitrag zu Akten der Petrus und Andreas. Zeitschrift für Kirchengeschichte. Bd. 5. Stuttgart, 1882. S. 506-509.

Budge 1901 - E. A. Wallis Budge. The Contendings of the Apostles: Being the Histories of the Lives and Martyrdoms and Deaths of the Twelve Apostles and Evangelists: The Ethiopic Texts with an English Translation. London, 1901.

Elliott 1993 - J. K. Elliott. The Apocryphal New Testament: A Collection of Apocryphal Christian Literature in an English Translation. Oxford, 1993.

Damjanović 2008 - S. Damjanović. Jezik hrvatskih glagoljaša. Zagreb, 2008.

Grabar 1967 - B. Grabar. Apokrifna Djela apostolska u hrvatskoglagoljskoj literaturi 1. Djela Andrije i Mateja u gradu ljudoždera 2. Djela apostola Petra i Andrije // Radovi Staroslavenskog instituta, Vol. 6. 1967. № 6. S. 109-208. 
Jagić $1879-$ V. Jagić. Quattuor evangeliorum codex glagoliticus olim Zographensis nunc Petropolitanus. Berolini, 1879.

Jagić 1883 - V. Jagić. Quattuor Evangeliorum versionis palaeoslovenicae codex Marianus Glagoliticus characteribus Cyrillicis transcriptum. Berolini, 1883.

Kapetanović 2011 - A. Kapetanović. Čakavski hrvatski književni jezik // Povijest hrvatskoga jezika 2. knjiga: 16. stoljeće. Zagreb, 2011. S. 77-123.

Lewis $1904-$ A. S. Lewis. The Mythological Acts of the Apostles: Translated from an Arabic MS. in the Convent of Deyr-es-Suriani, Egypt, and from MSS in the Convent of St. Catherine on Mount Sinai and in the Vatican Library. London, 1904.

Malan 1871 - S. C. Malan (ed.). The Conflicts of the Holy Apostles: An Apocryphal Book of the Early Eastern Church. London, 1871.

Milčetić 1902 - I Milčetić. Prilozi za literaturu hrvatskih glagoljskih spomenika III. Hrvatski Lucidar // Starine. Knj. 30. 1902. S. 257-334.

Sudec 2012 - S. Sudec. Naknadni zapisi u Žgombićevu zborniku i mjesto njegova nastanka // Slovo. 62. 2012. S. 233-234.

Štefanić $1969-V$. Štefanić. Hrvatska književnost srednjega vijeka. Zagreb, 1969.

Štefanić $1970-V$. Štefanić. Glagoljski rukopisi Jugoslavenske akademije. II dio. Zagreb, 1970.

Tischendorf $1866-$ C. Tischendorf. Apocalypses apocryphae: Mosis, Esdrae, Pauli, Iohannis, item Mariae dormitio, additis evangeliorum et actuum apocryphorum supplementis. Lipsiae, 1866.

Walker $1870-$ A. Walker. Apocryphal Gospels, Acts and Revelations. Edinburgh, 1870 .

Васильевский 1877 - В. Васильевский. Русско-византийские отрывки. V. Хождение апостола Андрея в стране Мирмидонян // Журнал Министерства народного просвещения. Ч. 189. Январь. СПб., 1877. С. 41-82.

Гранстрем $1953-$ Е. Э. Гранстрем. Описание русских и славянских пергаментных рукописей. Рукописи русские, болгарские, молдовлахийские, сербские. Л., 1953.

Дурново $2000-$ H. Н. Дурново. Русские рукописи XI и XII вв. как памятники старославянского языка // Дурново Н. Н. Избранные работы по истории русского языка. М., 2000. С. 391-494.

Истомин $1904-$ К. Истомин. Из славянорусских рукописей об апостоле Андрее. СПб., 1904. С. 11-14.

ПВЛ 1996 - Повесть временных лет. Подгот. текста, пер., ст. и коммент. Д. С. Лихачева. 2-е изд., испр. и доп. СПб. 1996.

Понырко 1987 - Н. В. Понырко. Слово святых апостол: Петра и Андрея, Матфея и Руфа, и Александра // Словарь книжников и книжности Древней Руси. Вып. 1 (XI - первая половина XIV в.). Отв. ред. Д. С. Лихачев. Л., 1987. С. 439-441.

Понырко, Панченко $1987-$ Н. В. Понырко, А. М. Панченко. Апокрифы о Андрее Первозванном // Словарь книжников и книжности Древней Руси. Вып. 1 (XI - первая половина XIV в.). Отв. ред. Д. С. Лихачев. Л., 1987. С. 49-54. 
Творогов 1988 - О. В. Творогов. Древнерусские четьи сборники XII-XIV вв. Статья первая // Труды Отдела древнерусской литературы. 1988. Т. 41. С. 197-214.

Творогов 1993 - О. В. Творогов. Древнерусские четьи сборники XII-XIV вв. Статья третья // Труды Отдела древнерусской литературы. 1993. Т. 47. С. 3-33.

Тихонравов $1863-H$. С. Тихонравов. Памятники отреченной русской литературы. Т. 2. М., 1863. С. 5-10.

\author{
Keiko Mitani \\ The University of Tokyo \\ (Japan, Tokyo) \\ kmitani@mb1.suisui.ne.jp
}

\title{
TEXT-CRITICAL AND LINGUISTIC ANALYSIS OF SLAVONIC COPIES OF THE APOCRYPHAL ACTS OF PETER AND ANDREW IN THE LAND OF BARBARIANS
}

The paper analyzes Slavonic copies of the apocryphal Acts of Peter and Andrew in the land of Barbarians from a text-critical perspective. This text was composed in the early Christian cultural milieu of the third or fourth centuries. The apocryphon was introduced to the Slavic world from Byzantium no later than the twelfth century. A total of four Slavonic witnesses are known, three of which are of Russian provenance, and one in the sixteenth-century Croatian Glagolitic script. Our textual analysis revealed that the four Slavonic copies are derived from a single Church Slavonic translation of the Greek original. The Glagolitic copy, for which the existence of a Cyrillic source is almost certain, follows the Greek text closely despite its use of local dialect. In contrast, the Russian copies, though fragmentary, clearly show Old Russian language features of the earliest times, but contain some textual divergences. These divergences are supposed to have appeared in the early stage of the formation of the Russian recension.

Key words: history of Slavic translated literature, apocrypha, Old Slavic manuscripts.

\section{References}

Badurina-Stipčević V. Glagoljski Žgombićev zbornik kao književni izvor. Kolo, 2. 2015 (http://www.matica.hr/kolo/460/). (In Serb.)

Bonnet M., Lipsius R. A., Tischendorf C. Passio Andreae. Ex actis Andreae. Martyria Andreae. Acta Andreae et Matthiae. Acta Petri et Andreae. Passio Bartholomaei. Acta Joannis. Martyrium Matthaei. Leipzig, 1898.

Bonwetsch N. Ein Beitrag zu Akten der Petrus und Andreas. Zeitschrift für Kirchengeschichte. Bd. 5. Stuttgart, 1882, S. 506-509. (In Germ.) 
Budge, E. A. Wallis. The Contendings of the Apostles: Being the Histories of the Lives and Martyrdoms and Deaths of the Twelve Apostles and Evangelists: The Ethiopic Texts with an English Translation. London, 1901.

Durnovo N. N. Russkie rukopisi XI i XII vv. kak pamyatniki staroslavyanskogo yazyka. In: Durnovo N. N. Izbrannye raboty po istorii russkogo yazyka. Moscow, 2000, p. 391-494.

Elliott J. K. The Apocryphal New Testament: A Collection of Apocryphal Christian Literature in an English Translation. Oxford, 1993.

Damjanović S. Jezik hrvatskih glagoljaša. Zagreb, 2008.

Grabar B. Apokrifna Djela apostolska u hrvatskoglagoljskoj literaturi 1. Djela Andrije i Mateja u gradu ljudoždera 2. Djela apostola Petra i Andrije. Radovi Staroslavenskog instituta, Vol. 6. 1967, No. 6, p. 109-208. (In Serb.)

Granstrem E. E. Opisanie russkikh i slavyanskikh pergamentnykh rukopisei. Rukopisi russkie, bolgarskie, moldovlakhiyskie, serbskie. Leningrad, 1953.

Istomin K. Iz slavyanorusskikh rukopisei ob apostole Andree. St. Petersburg, 1904, p. 11-14.

Jagić V. Quattuor evangeliorum codex glagoliticus olim Zographensis nunc Petropolitanus. Berolini, 1879.

Jagić V. Quattuor Evangeliorum versionis palaeoslovenicae codex Marianus Glagoliticus characteribus Cyrillicis transcriptum. Berolini, 1883.

Kapetanović A. Čakavski hrvatski književni jezik. Povijest hrvatskoga jezika. Vol. 2: 16th cent.. Zagreb, 2011, s. 77-123.

Lewis A. S. The Mythological Acts of the Apostles: Translated from an Arabic MS. in the Convent of Deyr-es-Suriani, Egypt, and from MSS in the Convent of St. Catherine on Mount Sinai and in the Vatican Library. London, 1904.

Malan, S. C. (ed.). The Conflicts of the Holy Apostles: An Apocryphal Book of the Early Eastern Church. London, 1871.

Milčetić I. Prilozi za literaturu hrvatskih glagoljskih spomenika III. Hrvatski Lucidar. Starine. Vol. 30. 1902, p. 257-334.

Ponyrko N.V. Slovo svyatykh apostol: Petra i Andreya, Matfeya i Rufa, i Aleksandra. Slovar' knizhnikov i knizhnosti Drevnei Rusi. Part 1 (XI - pervaya polovina XIV v.). Ed. D. S. Likhachev. Leningrad, 1987, p. 439-441.

Ponyrko N. V., Panchenko A. M. Apokrify o Andree Pervozvannom. Slovar' knizhnikov i knizhnosti Drevnei Rusi. Part 1 (XI — pervaya polovina XIV v.). Ed. D. S. Likhachev. Leningrad, 1987, p. 49-54.

Povest' vremennykh let. Ed. D. S. Likhachev. 2-nd ed., rev. St. Petersburg, 1996.

Sudec S. Naknadni zapisi u Žgombićevu zborniku i mjesto njegova nastanka. Slovo, 62. 2012, p. 233-234.

Štefanić V. Hrvatska književnost srednjega vijeka. Zagreb, 1969.

Štefanić V. Glagoljski rukopisi Jugoslavenske akademije. II dio. Zagreb, 1970. 
Tikhonravov N. S. Pamyatniki otrechennoi russkoi literatury. Vol. 2. Moscow, 1863, p. $5-10$.

Tischendorf C. Apocalypses apocryphae: Mosis, Esdrae, Pauli, Iohannis, item Mariae dormitio, additis evangeliorum et actuum apocryphorum supplementis. Lipsiae, 1866.

Tvorogov O. V. Drevnerusskie chet'i sborniki XII-XIV vv. Stat'ya pervaya. Trudy Otdela drevnerusskoi literatury. 1988. Vol. 41, p. 197-214.

Tvorogov O. V. Drevnerusskie chet'i sborniki XII-XIV vv. Stat'ya tret'ya. Trudy Otdela drevnerusskoi literatury. 1993. Vol. 47, p. 3-33.

Vasil'yevskiy V. Russko-vizantiyskie otryvki. 5. Khozhdenie apostola Andreya v strane Mirmidonyan. Zhurnal Ministerstva narodnogo prosveshcheniya. Part 189: January. St. Petersburg, 1877, p. 41-82.

Walker A. Apocryphal Gospels, Acts and Revelations. Edinburgh, 1870. 